\title{
Regulation of Biosynthesis and Release of Pars Intermedia Peptides in Rana ridibunda: Dopamine Affects Both Acetylation and Release of $\alpha-\mathrm{MSH}$
}

\author{
B. G. JENKS, ${ }^{*}$ B. M. L. VERBURG VAN KEMENADE,* \\ M. C. TONON† AND H. VAUDRY $\dagger^{\dagger}$ \\ *Department of Zoology, Faculty of Science, Catholic University, 6525 ED Nijmegen, The Netherlands \\ †Groupe de Recherche en Endocrinologie Moléculaire, UA CNRS 650, Unité Alliée INSERM \\ Faculté des Sciences, Université de Rouen, 76130 Mont-Saint-Aignan, France
}

Received 13 December 1984

\begin{abstract}
JENKS, B. G., B. M. L. VERBURG VAN KEMENADE, M. C. TONON AND H. VAUDRY. Regulation of biosynthesis and release of pars intermedia peptides in Rana ridibunda: Dopamine affects both acetylation and release of $\alpha-M S H$. PEPTIDES 6(5) 913-921, 1985. - Dopamine is likely an important physiological melanotropin release-inhibiting factor in amphibians. This study concerns the effects of dopamine on the biosynthesis and release of peptides from the pars intermedia of the frog Rana ridibunda. Our results show that this secretagogue has no immediate effects on either the rate of biosynthesis of pro-opiomelanocortin nor on the direction of processing of this prohormone. Pulse-chase experiments revealed that dopamine inhibited the release of all newly synthesized POMC-related peptides in a dose-dependent manner. For each dopamine concentration tested, the degree of inhibition exerted on the release of the various newly synthesized peptides by a given concentration of secretagogue was approximately the same, with the exception of that found for the $\alpha$-MSH related peptides. Analysis of the release of these melanotropins was complex because dopamine not only inhibited their release but also, either directly or indirectly, inhibited the acetylation reaction which converts des- $\mathrm{N} \alpha$-acetyl $\alpha$-MSH to $\alpha$-MSH. Dopamine was shown to be less potent in inhibiting the release of des-N $\alpha$-acetyl $\alpha$-MSH than inhibiting release of the acetylated form of the peptide. In amphibians a preferential release of the less-bioactive non-acetylated form of MSH under inhibitory conditions induced by dopamine may be of physiological importance.
\end{abstract}

$\begin{array}{llccc}\text { Pro-opiomelanocortin Melanotropin Acetylation } & \text { Dopamine } & \text { Pars intermedia } & \text { Pulse-chase } \\ \text { Biosynthesis } & \text { High performance liquid chromatography } & \text { Amphibian } & \text { Rana ridibunda } & \end{array}$

PRO-OPIOMELANOCORTIN (POMC) is a multifunctional protein which, through tissue-specific processing, can give rise to a number of bioactive peptides including adrenocorticotropic hormone (ACTH), $\alpha$-melanocyte-stimulating hormone $(\alpha-\mathrm{MSH})$ and $\beta$-endorphin $[7,9,15]$. Coordinate regulation of the release of POMC-related peptides from POMC-producing cells was proposed by Guillemin et al. [11] on the basis of their observation that stress-induced elevations in plasma levels of ACTH were accompanied by parallel elevations in circulating levels of immunoassayable $\beta$-endorphin. This concept of coordinate regulation is supported by the results of a number of in vitro studies conducted with a mouse corticotrophin-producing tumor cell $[1,17,21]$ and with corticotrophs of the adenohypophysis of the rat $[25,26,31]$, mouse [1] and cow [2]. Radioimmunoassays of peptides released from these POMC-producing cells revealed that secretion of peptides derived from the prohormone occurred in parallel under both basal and acute release-stimulatory or release-inhibitory conditions induced by the addition of secretagogues to the incubation media. Evidence for non-coordinated or differential regulation of release of peptides from POMC-producing cells, whereby secretagogues can selectively stimulate or inhibit one group of POMC-related peptides over another, is less well documented. Randle et al. [24] reported a differential control of release of POMC-derived peptides from the pars intermedia of the rat by serotonin. They suggested that this differential regulation was achieved by intervention of the secretagogue with the direction of processing of POMC. Alternatively, as the rat lobe is known to contain two celltypes [29], the differential control might reflect differences in the regulation of these cells. In the amphibian Xenopus laevis it has been shown that the $\beta$-adrenergic agonist isoproterenol selectively inhibits the release of a POMC-related peptide, $\beta$-lipotropin, from the pars intermedia of this species $[19,20]$. The data suggested the existence of heteroge-

\footnotetext{
'Requests for reprints should be addressed to H. Vaudry.
} 


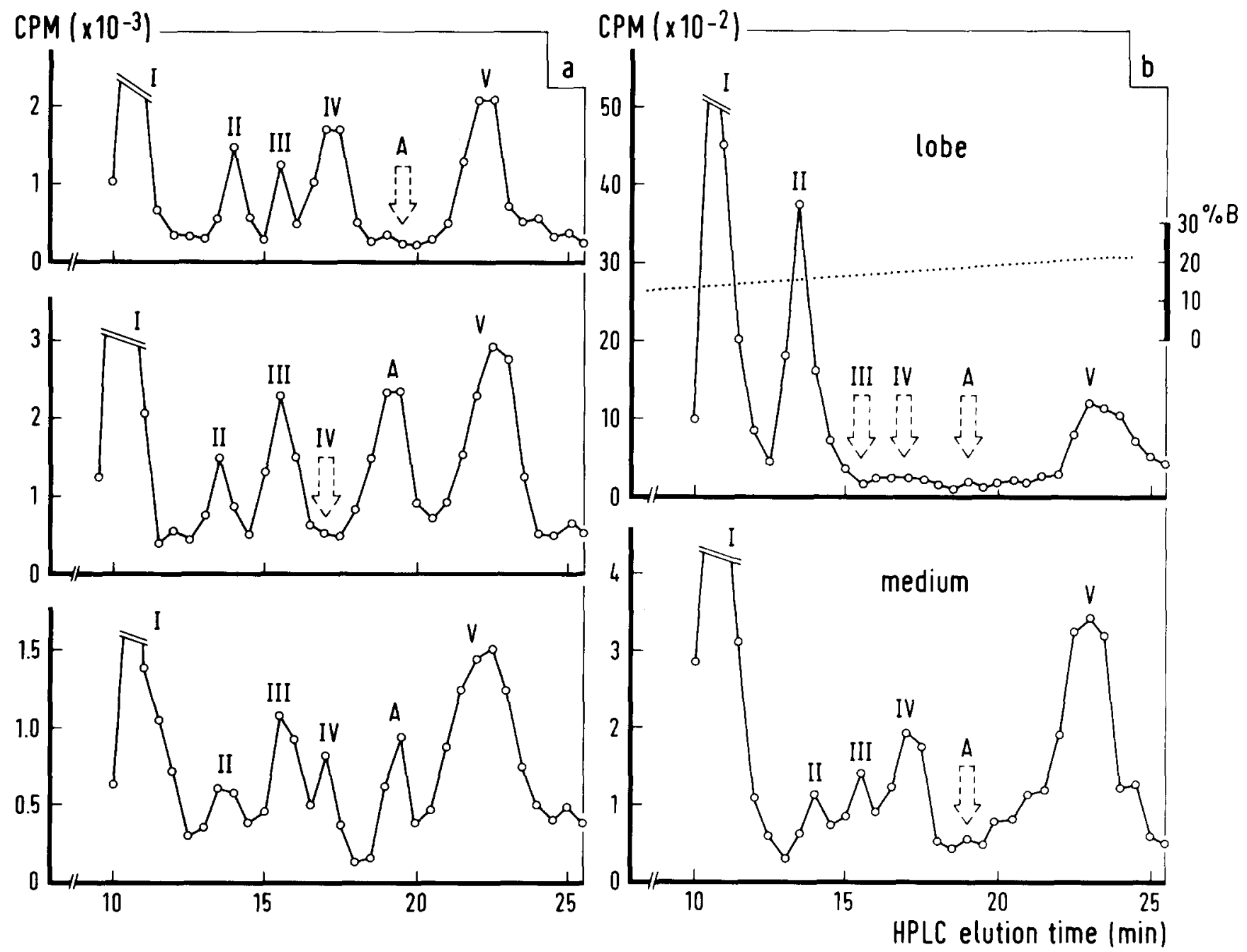

FIG. 1. (a) Examples of HPLC profiles of radiolabelled products released to the incubation medium during pulse-chase experiments with neurointermediate lobes of Rana ridibunda. Each example is from a different experiment using different lots of frogs. In all cases a mixture of radioactive amino acids was used in the labelling. The most common pattern is given in the upper profile (profile lacks product A). (b) HPLC profile for lobes and medium following a pulse-chase experiment with $\left[{ }^{3} \mathrm{H}\right]$-lysine. The radioactive profile shown was obtained by determining the radioactivity in a $20 \mu \mathrm{l}$ sample of each $1 \mathrm{ml}$ HPLC fraction. Fractions containing product III and product IV were used in the characterization studies shown in Fig. 2. Note that products III and IV are restricted to the incubation medium and that these lobes failed to synthesize product $\mathrm{A}$. The HPLC elution gradient used to produce all the profiles in this figure is shown in the upper right profile (\% secondary solvent, B).

neous pools of POMC-related peptides, possibly reflecting two cell types. The involvement of a $\beta$-adrenergic mechanism in the regulation of the Xenopus pars intermedia has never been established and thus the physiological significance of the above observation remains unclear.

In amphibians, there is considerable evidence to indicate that the neurotransmitter dopamine is an important physiological factor involved in the regulation of the pars intermedia $[4,10,18,30]$. In $R$ ana ridibunda, release of immunoreactive MSH is inhibited in a dose-dependent manner by the dopamine agonist apomorphine and this inhibitory action is blocked by the dopamine receptor antagonist haloperidol [30]. We have recently completed an in vitro study of the biosynthesis of peptides in pars intermedia of this same species [34]. Biosynthesis commenced with the production of a $36 \mathrm{~K}$ ( $\mathrm{K}=$ kilodaiton) prohormone during a pulseincubation in radioactive amino acids. In subsequent chaseincubations the radioactive prohormone was cleaved to produce a number of small peptides including $\gamma$-MSH, des$\mathrm{N} \alpha$-acetyl $\alpha$-MSH, corticotropin-like intermediate lobe pep- tide (CLIP) and an endorphin-like peptide. Following their biosynthesis the radioactive peptides were slowly secreted to the incubation medium. Pulse-chase analysis of the release of these peptides has an advantage over other techniques, such as radioimmunoassays, in that the release of all peptides derived from POMC can be studied simultaneously. In the present investigation we have applied this technique to examine the effects of dopamine on the release of POMCrelated peptides synthesized by the frog pars intermedia. For our analysis, it was crucial to first determine if dopamine has any immediate effect on the biosynthesis or the direction of intracellular processing of the prohormone. Therefore, experiments were also conducted to study the effect of dopamine on the in vitro incorporation of radioactive amino acids into the POMC-related peptides.

\section{METHOD}

\section{Animals}

Adult male frogs (Rana ridibunda) were purchased from 


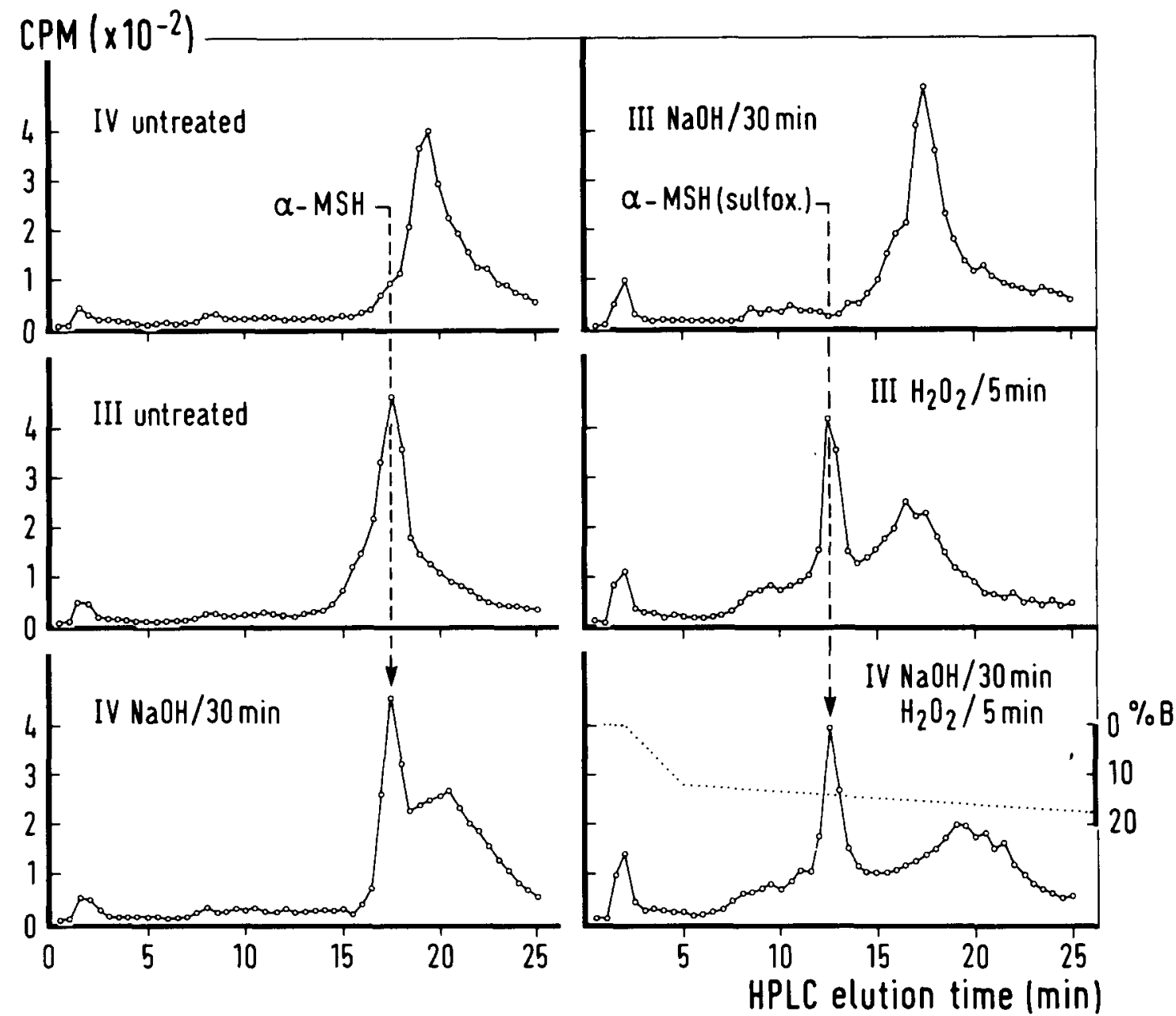

FIG. 2. Characterization of radiolabelled products III and IV. The HPLC gradient used in these studies is given in the lower right (\% secondary solvent B) and the elution position of synthetic $\alpha-\mathrm{MSH}$ and sulfoxidated $\alpha$-MSH is indicated. $\mathrm{NaOH}$ treatment was given to remove potential $\mathrm{O}$-linked acetyl groups and $\mathrm{H}_{2} \mathrm{O}_{2}$ treatment was given to form potential sulfoxide forms of the peptides.

Couétard, Saint-Hilaire de Riez, France. The animals were maintained in plastic tanks on a black background with constant illumination for one week prior to being used in the experiments. The purpose of the black-background adaptation was to induce high rates of peptide biosynthesis in the pars intermedia [34].

\section{Characterization of Melanotropins}

The pars intermedia of Rana synthesizes the nonacetylated form of $\alpha$-MSH (designated product $\mathrm{Il}$ in a previous study [34]) which is subsequently modified to form two structurally closely related peptides (designated products III and IV). To establish the acetylation status of these latter two peptides, or to determine if one of them might represent the sulfoxide form of the other, radiolabelled samples of these peptides were treated with $\mathrm{NaOH}$ (a treatment which removes the $\mathrm{O}$-linked acetyl group from $\mathrm{N}$, O-di-acetyl $\alpha$-MSH) or with $\mathrm{H}_{2} \mathrm{O}_{2}$ (to form potential sulfoxide derivatives of these peptides). To obtain the radiolabelled peptides, ten neurointermediate lobes of Rana were incubated for $8 \mathrm{hr}$ at $22^{\circ} \mathrm{C}$ in $200 \mu$ incubation medium containing $250 \mu \mathrm{Ci}\left[{ }^{3} \mathrm{H}\right]-$ lysine ( $90 \mathrm{Ci} \mathrm{mmole}{ }^{-1}$ ) and, following a brief rinse, were chase-incubated for $15 \mathrm{hr}$ in medium containing L-lysine (2 $m M)$. Condition for the incubations were the same as those reported previously [34] and briefly summarized below. Following incubation the lobes were extracted in $1 \mathrm{ml} 0.1 \mathrm{~N}$ $\mathrm{HCl}$, the medium was acidified to $0.1 \mathrm{~N}$ in $\mathrm{HCl}$, and both the lobe extract and medium were submitted to high performance liquid chromatography (HPLC), as outlined below. A $20 \mu$ sample of each 0.5 min HPLC-fraction (volume of each fraction was $1 \mathrm{ml}$ ) was taken, $2 \mathrm{ml}$ scintillation fluid was added to each sample and the radioactivity in each sample determined. From the radioactive profiles obtained those fractions containing radiolabelled products III and IV were determined, these were divided into a number of samples, 20 $\mu \mathrm{g}$ poly-pep (Sigma) was added to each sample and they were dried by vacuum centrifugation. These peptides were then submitted to HPLC, either as untreated samples or treated with $50 \mu \mathrm{l} 0.01 \mathrm{~N} \mathrm{NaOH}\left(30 \mathrm{~min}, 37^{\circ} \mathrm{C}\right)$ or with $50 \mu \mathrm{l}$ $30 \% \mathrm{H}_{2} \mathrm{O}_{2}(5 \mathrm{~min}$, room temperature) prior to chromatographic analysis. Following HPLC the amount of radioactivity in each HPLC-fraction was determined. The elution position of synthetic $\alpha$-MSH (Sigma) and its sulfoxide form (produced by treating the synthetic peptide with $\mathrm{H}_{2} \mathrm{O}_{2}$ ) were determined by submitting these peptides to HPLC and assaying each fraction with a radioimmunoassay for $\alpha-\mathrm{MSH}$. 
TABLE 1

EFFECTS OF DOPAMINE ON THE BIOSYNTHESIS AND PROCESSING OF POMC-RELATED PEPTIDES IN NEUROINTERMEDIATE LOBES OF RANA RIDIBUNDA

\begin{tabular}{lccc}
\hline Peptide & $\begin{array}{c}\text { Radioactivity } \\
\text { Control }(\mathrm{n}=5)\end{array}$ & $\begin{array}{l}\text { (CPM } \pm \text { SEM) } \\
\text { Dopamine( }=6)\end{array}$ \\
\hline $\begin{array}{l}\gamma \text {-MSH (I) } \\
\text { des-N } \alpha \text {-acetyl } \alpha \text {-MSH (II) }\end{array}$ & $4,283 \pm$ & 222 & $4,674 \pm 651$ \\
$\gamma$-MSH intermediate (V) & $2,650 \pm$ & 123 & $3,164 \pm 461$ \\
endorphin-like-peptide & $3,076 \pm$ & 419 & $3,363 \pm 399$ \\
$\quad(V I)$ & $6,918 \pm 828$ & $9,058 \pm 1,076$ \\
CLIP (VII) & & & \\
POMC/16K fragment (XI) & $22,247 \pm 3,243$ & $23,352 \pm 3,635$ \\
\hline
\end{tabular}

Lobes were pre-incubated in absence (control) or presence of dopamine $\left(10^{-5} \mathrm{M}\right)$ for $2 \mathrm{hr}$ and then incubated for $4 \mathrm{hr}$ in radioactive amino acids $\left(\left[{ }^{3} \mathrm{H}\right]\right.$-lysine, $\left[{ }^{3} \mathrm{H}\right]$-leucine mixture). Treatment with dopamine was continued during radioactive labeling. Following incubations each lobe was extracted and the extract submitted to HPLC. From the HPLC profile obtained, the radioactivity corresponding to various POMC-related peptides were then determined for each lobe. Results given are the mean $( \pm S E M)$ of radioactivity incorporated into the newly synthesized peptides. Analysis with Student's $t$ test show that there is no significant difference $(p>0.10)$ between level of individual products in the control and dopamine treated groups.

Conditions for the radioimmunoassay have been reported elsewhere [32].

\section{Analysis of POMC Biosynthesis and Processing}

Because it was our intention to quantify the effect of dopamine upon the incorporation of radioactive amino acids into POMC-related peptides, animals of approximately the same size $(40 \mathrm{~g})$ were selected for these experiments. The frogs were decapitated between $0800-0900 \mathrm{hr}$ and the neurointermediate lobes were dissected out immediately. The lobes were pre-incubated for $2 \mathrm{hr}$ in $500 \mu \mathrm{l}$ normal incubation medium (controls) or in $500 \mu \mathrm{l}$ incubation medium containing $10^{-5} \mathrm{M}$ dopamine. The composition of the incubation medium was as follows: $112 \mathrm{mM} \mathrm{NaCl}, 2 \mathrm{mM} \mathrm{CaCl} \mathrm{l}_{2}$, $2 \mathrm{mM} \mathrm{KCl}, 15 \mathrm{mM}$ Hepes, $2 \mathrm{mg} / \mathrm{ml}$ glucose, $0.3 \mathrm{mg} / \mathrm{ml}$ bovine serum albumin and $1 \mu \mathrm{g} / \mathrm{ml}$ ascorbic acid. Cell incubations were conducted at $22^{\circ} \mathrm{C}$ and the incubation medium was gassed for 15 min with $\mathrm{O}_{2}-\mathrm{CO}_{2}(95: 5)$ and $\mathrm{pH}$ adjusted to 7.3 prior to use. Following the pre-incubation the lobes were incubated individually in $50 \mu \mathrm{l}$ of medium containing $40 \mu \mathrm{Ci}$ $\left[{ }^{3} \mathrm{H}\right]$-lysine (90 Ci mmole ${ }^{-1}$, Amersham) and $40 \mu \mathrm{Ci}\left[{ }^{3} \mathrm{H}\right]-$ leucine $\left(50 \mathrm{Ci} \mathrm{mmole}^{-1}\right.$, Amersham) for $4 \mathrm{hr}$. Dopamine $\left(10^{-.5}\right.$ M) was also present in the medium of the dopamine-treated group during these later incubations. The lobes were then individually homogenized in $500 \mu \mathrm{l}$ chilled $0.1 \mathrm{~N} \mathrm{HCl}$ and each extract stored frozen until analyzed by HPLC.

\section{Analysis of Release of POMC-Related Peptides}

Neurointermediate lobes were incubated for $4 \mathrm{hr}$ in $65 \mu \mathrm{l}$ medium containing $40 \mu \mathrm{Ci}$ each of $\left[{ }^{3} \mathrm{H}\right]$-lysine $(90 \mathrm{Ci}$ mmole $\left.^{-1}\right),\left[{ }^{3} \mathrm{H}\right]$-leucine (50 Ci mmole $\left.{ }^{-1}\right),\left[{ }^{3} \mathrm{H}\right]$-phenylalanine (115 $\mathrm{Ci} \mathrm{mmole}{ }^{-1}$ ) and $\left[{ }^{3} \mathrm{H}\right]$-tyrosine (45 $\mathrm{Ci}$ mmole $^{-1}$ ) all purchased from Amersham. Following this pulse-incubation each lobe was rinsed three times in medium containing $2 \mathrm{mM}$ lysine, $2 \mathrm{mM}$ leucine, $2 \mathrm{mM}$ phenylalanine and $2 \mathrm{mM}$ tyrosine (chase-incubation medium). Lobes were then incubated individually for $6 \mathrm{hr}$ in normal medium (control) or in medium containing dopamine $\left(10^{-8} \mathrm{M}, 10^{-7} \mathrm{M}, 10^{-6 i} \mathrm{M}\right.$ or $\left.10^{-5} \mathrm{M}\right)$. In each case the volume of the chase-medium was $200 \mu \mathrm{l}$ and it was replaced with fresh medium every $2 \mathrm{hr}$ during the course of the chase incubation. The collected medium was acidified to a final concentration of $0.1 \mathrm{~N} \mathrm{HCl}$ and frozen immediately. At the end of the incubations each lobe was extracted and both lobe extracts and media were kept frozen until HPLC analysis.

\section{High Performance Liquid Chromatography}

Separation of newly synthesized radioactive peptides was accomplished by reverse-phase HPLC using a Spherisorb 10 ODS-column (Chrompack) with $0.5 \mathrm{M}$ formic acid, $0.14 \mathrm{M}$ pyridine ( $\mathrm{pH} 3.0$ ) as the primary solvent and a gradient elution established with l-propanol. A flow rate of $2.0 \mathrm{ml} / \mathrm{min}$ was used and $0.5 \mathrm{~min}$ fractions were collected. To each fraction $4 \mathrm{ml}$ of scintillation liquid (Scintillator 299, Packard) was added and the radioactivity determined on a liquid scintillation analyser. The media collected from individual lobes during the pulse-chase experiments were pooled prior to HPLC analysis. For comparing the radioactivity associated with each peak a standard procedure was adopted whereby the two highest cpm-values of each peak in each HPLC-profile were taken.

\section{Statistics}

Results were analyzed for significance with the Student's $t$ test. All values are reported as mean + SEM except where data are from individual animals.

\section{RESULTS}

\section{Identification of Acetylated Forms of $\mathrm{MSH}$}

In reviewing our HPLC incubation-media profiles obtained from a number of biosynthetic studies using different lots of frogs, all purchased from the same commercial supplier, it is evident that with respect to products III and IV, differences in pattern of release occur (Fig. la). The most common pattern is that both products III and IV are present in the incubation medium (Fig. 1a, top profile), a situation that was the rule in our previous studies $[33,34]$. Another pattern found is that product III is present, product IV is absent, and a new product, labelled A, is present (Fig. la, middle profile). This is the pattern found in the present studies (see Fig. 3). A third pattern, only occasionally encountered, is characterized by the presence of products III, IV and A (Fig. 1a, bottom profile). In attempting to isolate radiolabelled peptides for further characterization, the lobes used synthesized products III and IV but failed to produce product A (Fig. 1b). Thus, at present, it is not possible to further characterize this latter peptide. The presence of products III and IV were restricted to the incubation medium, a characteristic that they hold in common with product A (see for example, Fig. 3).

Previous tryptic mapping studies [33] showed that products II, III and IV all contain the ACTH(8-13) $\mathrm{NH}_{2}$ tryptic fragment, as expected for $\alpha$-MSH related peptides. Product II also generated the ACTH(1-7) fragment and thus its identity as the non-acetylated form of $\alpha$-MSH (des- $N \alpha$-acetyl $\alpha$-MSH) was established. The $\mathrm{N}$-terminal tryptic fragments of both product III and product IV had longer HPLC reten- 


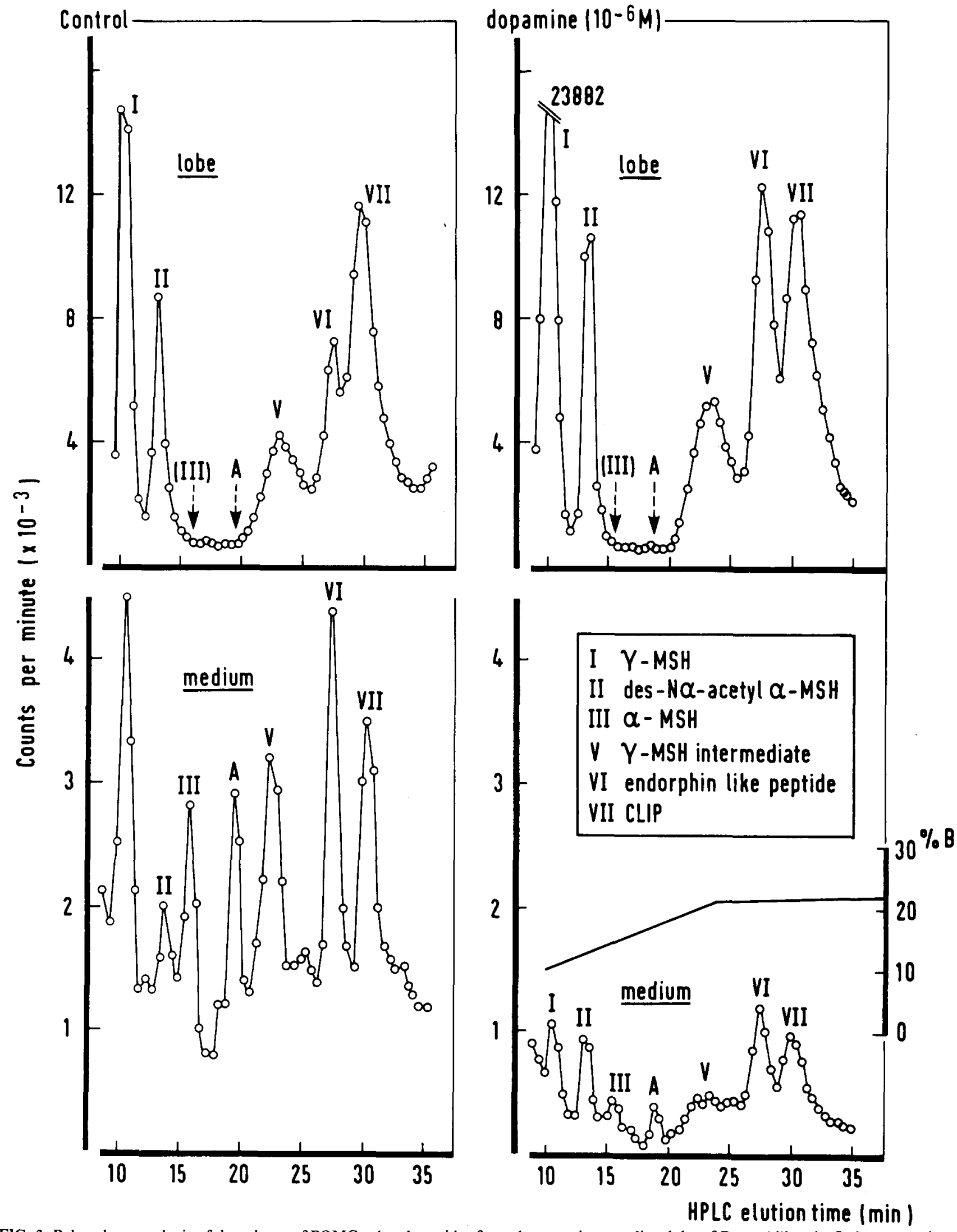

FIG. 3. Pulse-chase analysis of the release of POMC-related peptides from the neurointermediate lobe of Rana ridibunda. Lobes were given a $4 \mathrm{hr}$ pulse-incubation in medium containing a mixture of $\left[{ }^{3} \mathrm{H}\right]$-lysine, $\left[{ }^{3} \mathrm{H}\right]$-leucine, $\left[{ }^{3} \mathrm{H}\right]$-phenylalanine and $\left[{ }^{3} \mathrm{H}\right]$-tyrosine and then chaseincubated for $6 \mathrm{hr}$ in normal medium (control) or in medium containing $10^{-6} \mathrm{M}$ dopamine. Lobe extracts and media were then submitted to HPLC. Identity of the radioactive peptides are given in the insert in the lower right. Also shown is the elution gradient used (\% secondary solvent, B). Note the expanded scale of medium profiles. 

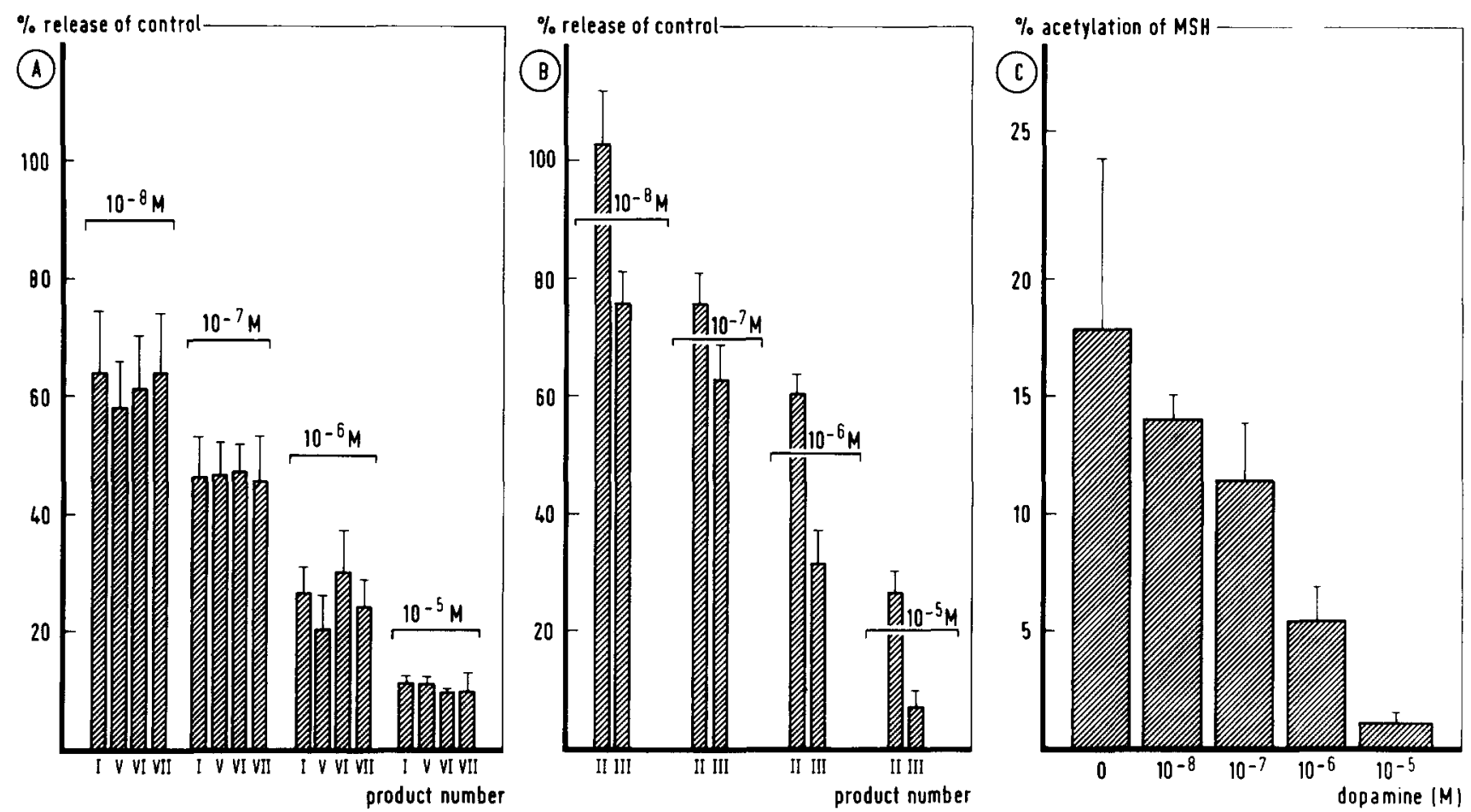

FIG. 4. (A) Effect of dopamine on the release of newly synthesized $\gamma$-MSH (product I), $\gamma$-MSH-intermediate (product V), endorphin-like peptide (product VI) and CLIP (product VII) during pulse-chase experiments. Results are expressed as percent release ( \pm SEM) relative to that displayed by control lobes. At each concentration of dopamine no significant difference $(p>0.05)$ was found in the degree of inhibition induced by dopamine among the various peptides. (B) Effect of dopamine on the release of newly synthesized des- $\mathrm{N} \alpha$-acetyl $\alpha$-MSH (product II) and $\alpha$-MSH (products III) during pulse-chase experiments. Results are expressed as percent release ( \pm SEM) of that displayed by control lobes. At each concentration of dopamine tested it induced a significantly greater inhibition on $\alpha$-MSH than on des-N $\alpha$-acetyl $\alpha$-MSH $(p<0.05)$, except for the $10^{-7} \mathrm{M}$ dose. (C) Effects of dopamine on the acetylation of des-N $\alpha$-acetyl $\alpha$-MSH (product II) to form acetylated $\alpha$-MSH (product III). The percent of the MSH present in the acetylated form relative to total MSH (lobe plus medium) are given for the control and dopamine treated tissue. Values are the average $( \pm S E M)$ obtained from the same experiments as those described above.
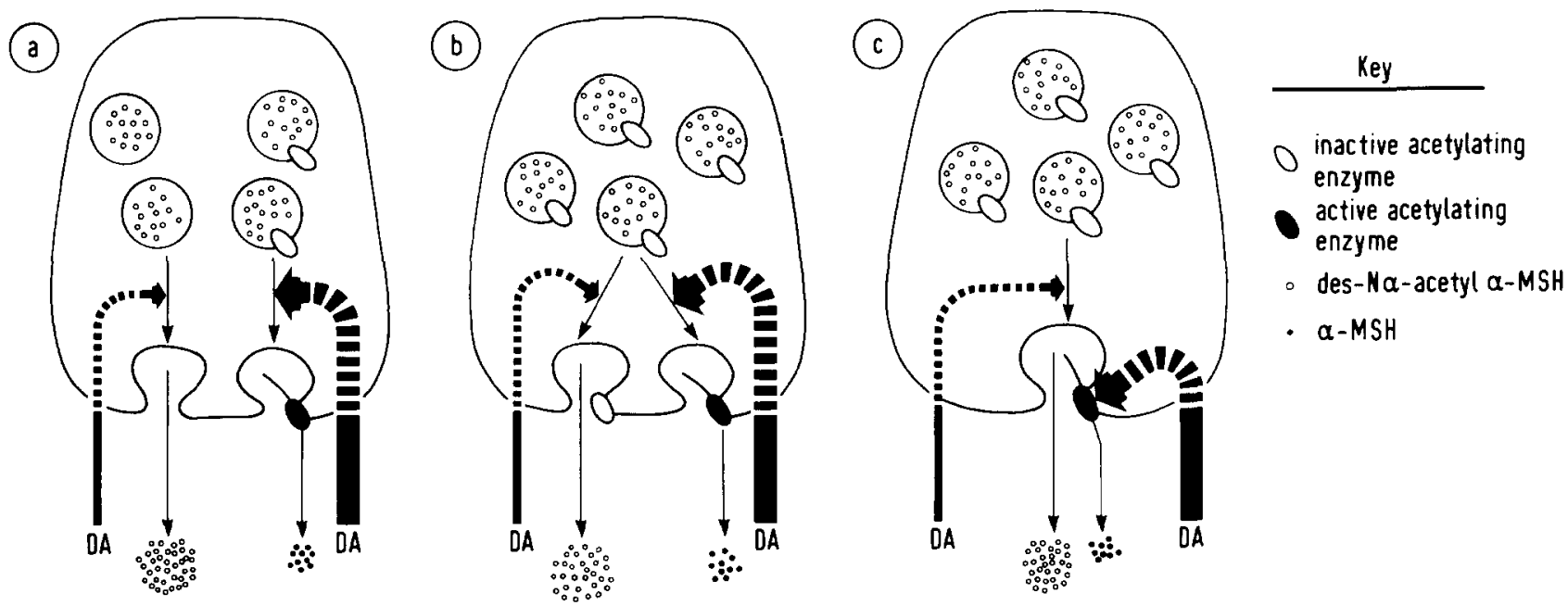

FIG. 5. Possible mechanisms whereby dopamine can exert a more potent inhibition on the release of $\alpha$-MSH than on the release of des-N $\alpha$-acetyl $\alpha$-MSH. (a) Independent compartments in which secretory granules are predestined to follow an acetylation-linked pathway or a non-acetylation pathway. (b) Independent secretory pathways for the release of acetylated and non-acetylated melanotropins from a single compartment or pool. (c) Independent action of dopamine on the acetylation system and the secretory process. The thickness of the arrow for the effect of dopamine (DA) is intended to give an indication of the relative strength of the inhibitory action exerted by the secretagogue. Thick arrows indicate stronger inhibitory action and the arrows are dotted within the cells to indicate the probable involvement of intracellular second messenger mechanisms. (Note: while the acetylation enzyme is shown to be associated with the secretory granule membrane and cell membrane its location remains to be established). 
tion times than the ACTH(1-7) peptide and in fact had elution characteristic very similar or identical to $\mathrm{N}$-acetyl ACTH(1-7). It was suggested that product IV was $\alpha$-MSH and that product III could be the sulfoxide form of this peptide. In the present study, where a shallower HPLC elution gradient is used to achieve higher resolution of these peptides (Fig. 2), it is evident that radiolabelled product III elutes in the position of $\alpha$-MSH. Moreover, with $\mathrm{H}_{2} \mathrm{O}_{2}$ treatment the elution position of this product shifts to that of the sulfoxide form of $\alpha$-MSH. $\mathrm{NaOH}$ treatment has no effect on the elution characteristic of product III. This same treatment on radiolabelled product IV generates a peptide that elutes in the position of product III. Finally, treatment of product IV first with $\mathrm{NaOH}$, and subsequently with $\mathrm{H}_{2} \mathrm{O}_{2}$, gives a product with elution characteristics identical to sulfoxidated $\alpha$-MSH. Altogether we conclude that product III is monoacetylated $\alpha$-MSH (N-acetyl $\alpha$-MSH) and that product IV is the diacetylated form of the peptide ( $N$, O-diacetyl $\alpha$-MSH).

Effects of Dopamine on Biosynthesis and Processing of $P O M C$

Table 1 gives the amount of POMC-related peptides synthesized by control and dopamine-treated tissue. The characterization and identification of these HPLC-resolved peptides, which involved selective amino acid incorporation, immunoprecipitation and tryptic and chymotryptic mapping has been reported earlier [34]. The radioactive peptides synthesized by the frog neurointermediate lobe were numbered I-XI according to their elution position from the HPLC column and the roman numerals given in the table refer to this previous designation. As this study involves an analysis of lobe-peptides only, those products whose presence is restricted to the incubation medium (product III, IV and A) $[33,34]$ are missing in this analysis. The identity of newly synthesized products VIII-X remains to be established and they were therefore excluded from the table. Since HPLC failed to separate POMC from the N-terminal $16 \mathrm{~K}$-fragment of this prohormone these proteins are analyzed together (peak XI).

No significant difference was found in the total radioactivity incorporated into POMC-related peptides between the control $(46,150 \pm 5,500 \mathrm{cpm})$ and dopamine-treated group $(57,500 \pm 11,050 \mathrm{cpm})(p>0.05)$. Also, when the level of radioactivity in individual products were compared no significant differences were found (Table 1).

Effects of Dopamine on the Release of

POMC-Related Products

Figure 3 gives an example of the HPLC analysis of a pulse-chase experiment for a control and a dopamine-treated lobe. The results presented are from frogs of approximately the same size. It is evident that for each newly synthesized peptide, the absolute amount released to the incubation medium by the dopamine-treated lobe is less than that released by the control lobe. Note that the relative reduction in the level of des- $\mathrm{N} \alpha$-acetyl $\alpha$-MSH (product II) in the incubation medium of the dopamine treated lobe compared to the medium of the control lobe is much less than the reduction displayed by the other peptides. Thus, product II becomes a major product in the dopamine medium profile.

Because it proved impossible to use animals of the same size throughout the pulse-chase experiments, the relative levels of release of each peptide, defined as the fraction of the total amount of radioactive peptide (lobe plus medium) that is secreted to the medium was considered in the further analysis of these data. In this manner it was possible to compare release between different sized lobes which, because of their size differences, had different levels of total radioactive incorporation. For the $\alpha$-MSH-related peptides (products II and III) the release of each peptide was determined relative to the total level of radioactive peptides (lobe plus medium) associated with this group of peptides.

Given in Fig. $4 \mathrm{~A}$ is the effect of dopamine, at concentrations ranging from $10^{-8} \mathrm{M}$ to $10^{-5} \mathrm{M}$, on the rate of release of $\gamma$-MSH (product I), $\gamma$-MSH intermediate (product V), endorphin-like-peptide (product VI) and CLIP (product VII) expressed as a percent of the relative rate of release displayed by control lobes. Dopamine suppressed the release of all these peptides in a dose-dependent manner and, at each concentration of dopamine tested, there was no significant difference in the degree of inhibition achieved for each peptide.

The effects of dopamine on the release of $\alpha$-MSH-related peptides is given in Fig. 4 (B). While dopamine suppressed the release of both the non-acetylated (product II) and the acetylated peptide (product III) in a dose-dependent manner, the degree of inhibition achieved was not the same for both peptides. At each concentration of dopamine tested the secretagogue was more potent in inhibiting the release of the acetylated form of the peptide than in inhibiting the nonacetylated peptide

In control experiments $\alpha$-MSH represent $17.8 \%$ of the total amount of newly synthesized $\alpha$-MSH plus des-N $\alpha$ acetyl $\alpha$-MSH (Fig. 4 (C)). Incubation in the presence of dopamine reduced the relative amount of acetylated peptide and this reduction occurred in the dose-dependent manner.

\section{DISCUSSION}

Previous biosynthetic studies have shown that neurointermediate lobes of the frog Rana ridibunda synthesize two peptides (products III and IV) which, on the basis of their amino acid composition, their bioactivities and immunoactivities, and their tryptic mapping charactistics were designated as acetylated forms of MSH $[33,34]$. The fact that product IV converts to product III at high $\mathrm{pH}$, a treatment shown to remove the $O$-linked acetyl group from $\mathrm{N}$, O-diacetyl $\alpha$-MSH [28], now establishes product IV as the diacetyl form of MSH and product III as the monoacetylated peptide. From the results of numerous biosynthetic studies it is evident that the relative level of production of these acetylated peptides can differ between groups of frogs, the most common pattern being synthesis of both the monoacetylated and diacetylated peptides. Occasionally, as is the case with the neurointermediate lobes used in the present study, only the monoacetylated peptide is formed. One feature these acetylated forms of MSH have in common is that their presence is restricted to the incubation medium. This observation has lead us to propose that acetylation of MSH in the pars intermedia of Rana is associated with the release process [33]. Possibly, electrochemical changes in the microenvironment of the secretory granule during the process of exocytosis activates an acetylation system for the $\mathrm{N}$-terminal acetylation of the peptide. It is evident that, in vitro at least, acetylation of the peptide population is not complete as some non-acetylated MSH (product II) is always present in the incubation medium.

The frogs used in the present study, while lacking the 
diacetylated form of $\alpha-\mathrm{MSH}$, synthesized a new peptide, designated product $A$. That there is probably no relationship between the lack of diacetylated $\alpha$-MSH and the presence of this new peptide is indicated by the fact that we have found some frogs capable of synthesizing both diacetyl $\alpha$-MSH and product $A$. As with the acetylated melanotropins, the presence of product $A$ was restricted to the incubation medium, suggesting that it could represent yet another form of MSH. We have been unable to obtain sufficient quantities of this peptide for characterization and therefore, in considering $\alpha$-MSH related peptides in the present study we have restricted our attention to only the fully characterized products, namely des- $\mathrm{N} \alpha$-acetyl $\alpha$-MSH (product II) and monoacetylated $\alpha-\mathrm{MSH}$ (product III).

It has been shown that factors which influence the secretory process in POMC-producing cells can also affect the rate of biosynthesis of the prohormone. For example, dexamethasone, a synthetic glucocorticoid known to inhibit the release of POMC-related peptides from the anterior pituitary $[1,25]$, also suppresses transcription of the POMC gene $[3,27]$. More relevant to the present investigation is the observation that chronic treatment of rats with dopamine agonists decreases the levels of POMC mRNA in the intermediate lobe of the rat [5] while treatment with antagonists increases mRNA levels $[5,16]$. Although dopamine has been shown to have a very rapid inhibitory effect on the secretion of melanotropins from the pars intermedia of Rana [30], it is clear from the present results that it had no direct effect on biosynthetic activity in the lobe. In addition, we observed that dopamine had no effect on the HPLC profile of newly synthesized peptides, which indicates that the secretagogue does not alter the direction of intracellular processing of POMC within the time constraints of our in vitro incubations. Thus, in the short term at least, the effects of dopamine on the pars intermedia of Rana are restricted to those exerted on the release process.

Our results show that dopamine inhibits the release of all newly-synthesized POMC-related peptides in a dosedependent manner. Moreover, the degree of inhibition of release exerted by any given concentration of dopamine was approximately the same on each peptide. This later observation was true for all products except those related to $\alpha$-MSH and was observed over a wide range of dopamine concentrations. Thus, these results in general support the concept of coordinate regulation of release of peptides from POMCproducing systems.

The fact that acetylation of MSH is associated with the release process has made the analysis of the release of $\alpha$-MSH related peptides more complex than that of the other peptides. Most surprising was the finding that dopamine had a significantly more potent inhibitory effect on the release of the acetylated form of $\alpha$-MSH compared to its effect on the release of des- $\mathrm{N} \alpha$-acetyl $\alpha$-MSH. Along these lines, Ham $e t$ al. $[13,14]$ have recently shown that dopamine may alter the post-translational processing of POMC-related peptides. In particlular, dopaminergic agents modify the acetylation of $\beta$-endorphin-derived peptides in rat pars intermedia cells in culture.

There are a number of possible explanations for the differential effect of dopamine on the release of the acetylated and non-acetylated melanotropin (see Fig. 5). The MSH destined for release in the non-acetylated form could be sequestered in a different compartment or "release pool" than MSH destined for acetylation (Fig. 5 (a)). The former compartment would be less sensitive to inhibition by dopamine and thus, the release of des- $\mathrm{N} \alpha$-acetyl $\alpha$-MSH is favoured under the inhibitory conditions induced by dopamine. An alternative on this theme would be a single compartment of peptides with two independent intracellular pathways for secretion (Fig. 5 (b)). One pathway, in which acetylation is associated with secretion of melanotropin, is more sensitive to dopamine inhibition than that displayed by the other pathway which releases primarily des- $\mathrm{N} \alpha$-acetyl $\alpha$-MSH. Another, perhaps simpler explanation, is that dopamine could have an inhibitory action on the acetylation enzyme or enzyme system independent of its inhibitory action on the secretory process (Fig. 5 (c)). An independent inhibition on the acetylation system could favour the release of des- $\mathrm{N} \alpha$-acetyl $\alpha$-MSH relative to the release of the acetylated peptide.

The present data do not allow us to give preference to any one of the proposed mechanisms over another. The observation, however, that release of des-N $\alpha$-acetyl $\alpha$-MSH is favoured over the acetylated peptide under inhibitory conditions induced by dopamine may be of physiological significance. The non-acetylated form of the peptide is known to be melanotropically less-potent $[8,12]$. In living frogs the melanotrophs of the pars intermedia of white-background adapted animals are under dopaminergic inhibition. Consequently, circulating levels of melanotropins are low and the skin displays a pale coloration. A possible contribution to this pallor could be that in such animals any MSH released would be in the less melanotropic non-acetylated form. Both the groups of O'Donohue [6, 22, 23] and Smyth [35,36] have proposed that regulation of $\mathrm{N}$-terminal acetylation reactions could constitute an important control point for modulation of the secretory signal from POMC-producing cells. An understanding of the regulation of acetylation of melanotropins in the pars intermedia of amphibians may make an important contribution in furthering this concept.

\section{ACKNOWLEDGEMENTS}

We are indebted to Drs. R. Andreatta and K. Scheibli (CibaGeigy, Basel, Switzerland) for their kind of gifts of synthetic $\alpha$-MSH and related peptides. This work was supported by research grants from the Institute National de la Santé et de la Recherche Médicale (82-4019 and 84-6020) and from the European Economic Community (STI-084-J-C). We thank Mrs. H. Overes for technical assistance and Mrs. I. Culembourg and I. Pastor for typing the manuscript.

\section{REFERENCES}

1. Allen, R. G., E. Herbert, M. Hinman, H. Shibuya and C. D. Pert. Coordinate control of corticotropin, $\beta$-lipotropin and $\beta$-endorphin release in mouse pituitary cell cultures. Proc Natl Acad Sci USA 75: 4972-4976, 1978.
2. Baird, A., W. B. Wehrenberg. T. Shibasaki, R. Benoit, Z. Chong-Li, F. Esch and N. Ling. Ovine corticotropin-releasing factor stimulates the concomitant secretion of corticotropin, $\beta$-lipotropin, $\beta$-endorphin and $\alpha$-melanotropin by bovine adenohypophysis in vitro. Biochem Biophys Res Commun 108: 959-964, 1982. 
3. Birnberg, N. C., J. C. Lissitzky, M. Hinman and E. Herbert. Glucocorticoids regulate proopiomelanocortin gene expression in vivo at the level of transcription and secretion. Proc Natl Acad Sci USA 80: 6982-6986, 1983.

4. Bower, A., M. E. Hadley and V. J. Hrubry. Biogenic amines and control of melanophore stimulating hormone release. Science 184: 70-72, 1974.

5. Chen, C. L. C., F. T. Dionne and J. L. Roberts. Regulation of pro-opiomelanocortin mRNA levels in rat pituitary by dopaminergic compounds. Proc Natl Acad Sci USA 80: 22112215,1983

6. Chappell, M. C., Y. P. Loh and T. L. O'Donohue. Evidence for an opiomelanotropin acetyltransferase in the rat pituitary neurointermediate lobe. Peptides 3: 405-410, 1982.

7. Chrétien, M. and N. G. Seidah. Chemistry and biosynthesis of pro-opiomelanocortin. Mol Cell Biochem 34: 101-127, 1981.

8. Eberle, A. N. Structure and chemistry of the peptide hormone of the intermediate lobe. In: Peptides of the Pars Intermedia, Ciba Foundation Symposium 81. Summit, NJ: Pitman Medical, 1981, pp. 13-31.

9. Eipper, B. A. and R. E. Mains. Structure and biosynthesis of pro-adrenocorticotropin/endorphin and related peptides. Endocr Rev 1: 1-27, 1980.

10. Goos, H. J. Th. and M. Terlou. Hypothalamic control of MSH secretion in lower vertebrates. In: Frontiers of Hormone Research. vol. 4, edited by T. B. Van Wimersma Greidanus. Basel: S. Karger, 1977, pp. 51-62.

11. Guillemin, R., T. Vargo, J. Rossier, S. Minick, N. Ling, C. Rivier, W. Vale and F. Bloom. $\beta$-Endorphin and adrenocorticotropin are secreted concomitantly by the pituitary gland. Science 197: 1367-1369, 1977.

12. Guttmann, S. T. and R. A. Boissonnas. Influence of the structure of the $\mathrm{N}$-terminal extremity of $\alpha$-MSH on the melanophore stimulating activity of this hormone. Experientia 17: 265-267, 1961 .

13. Ham, J., K. G. Mc Farthing, C. I. A. Toogood and D. G. Smyth. Influence of dopaminergic agents on $\beta$-endorphin processing in rat parts intermedia. Biochem Soc. Trans 12: 927-929, 1984.

14. Ham, J. and D. G. Smyth. Regulation of bioactive $\beta$-endorphin processing in rat pars intermedia. FEBS Lett 75: 407-411, 1984.

15. Herbert, E. Discovery of pro-opiomelanocortin, a cellular polyprotein. Trends Biochem Sci 6: 184-188, 1981.

16. Holt, V., I. Haarmann, B. R. Slizinger and A. Herz. Chronic haloperidol treatment increases the level of in vitro translatable $\mathrm{m}$-RNA coding for $\beta$-endorphin/ACTH precursor POMC in the pars intermedia of the rat. Endocrinology 110: 1885-1891, 1982.

17. Hook, V. Y. H., S. Heisler, S. L. Sabol and J. Axelrod. Corticotropin-releasing factor stimulates adrenocorticotropin and $\beta$-endorphin release from AtT-20 mouse pituitary cells. Biochem Biophys Res Commun 106: 1364-1371, 1982.

18. Jenks, B. G. Control of MSH synthesis and release in the aquatic toad Xenopus laevis. In: Frontiers of Hormone Research. vol. 4, edited by T. B. Van Wimersma Greidanus. Basel: $\mathbf{S}$. Karger, 1977, pp. 63-65.

19. Loh, Y. P. Processing, turnover and release of corticotrophin endorphins and melanotropin in the toad pituitary intermediate lobe. In: Peptides of the Pars Intermedia, Ciba Foundation Symposium 81. Summit, NJ: Pitman Medical, 1981, pp. 55-78.

20. Loh, Y. P. and B. G. Jenks. Evidence for two different pools of adrenocorticotropin, $\alpha$-melanocyte-stimulating hormone, and endorphin-related peptides released by the frog pituitary neurointermediate lobe. Endocrinology 109: 54-61, 1981.
21. Mains, R. E. and B. A. Eipper. Coordinate, equimolar secretion of smaller peptide products derived from pro-ACTH/endorphin by mouse pituitary tumor cells. J Cell Biol 89: 21-28, 1981.

22. O'Donohue, T. L. Opiomelanotropin acetyltransferase regulates actions of opiomelanotropinergic neurons. In: Integrative Neurohumoral Mechanisms, edited by E. Endröczi, Amsterdam: Elsevier Science Publishers, 1983, pp. 295-302.

23. O'Donohue, T. L. and M. C. Chappell. Distribution of an enzyme which acetylates $\alpha$-melanocyte stimulating hormone in rat brain and pituitary gland and effects of arcuate nucleus lesions. Peptides 3: 69-75, 1982.

24. Randle, J. C. R., B. C. Moor and J. Kraicer. Differential control of the release of proopiomelanocortin-derived peptides from the pars intermedia of the rat pituitary. Neuroendocrinology 37: 131-140, 1983.

25. Raymond, V., J. Lépine, J. C. Lissitzky, J. Côté and F. Labrie. Parallel release of ACTH, $\beta$-endorphin, $\alpha$-MSH and $\beta$ MSH-like immunoreactivities in rat anterior pituitary cells in culture. Mol Cell Endocrinol 16: 113-122, 1979.

26. Raymond, V., J. Lépine, V. Giguère, J. C. Lissitzky, J. Côté and F. Labrie. Parallel stimulation of ACTH, $\beta-\mathrm{LPH}$, $\beta$-endorphin and $\alpha$-MSH release by $\alpha$-adrenergic agents in rat anterior pituitary cells in culture. Mol Cell Endocrinol 22: 295$303,1981$.

27. Roberts, J. L., J. H. Eberwine and C. E. Gee. Analysis of POMC gene expression by transcription assay and in situ hybridization histochemistry. Cold Spring Harbor Symposia on Quantitative Biology 28: 385-391, 1983.

28. Rudman, D., R. K. Chawla, B. M. Hollins. N,O-diacetyl-serine $\alpha$-melanocyte-stimulating hormone, a naturally occurring melanotropic peptide. J Biol Chem 254: 10102-10108, 1979.

29. Stoeckel, M. E., G. Schmitt and A. Porte. Fine structure and cytochemistry of the mammalian pars intermedia. In: Peptides of the Pars Intermedia, Ciba Foundation Symposium 81. Summit, NJ; Pitman Medical, 1981, pp. 101-127.

30. Tonon, M. C., P. Leroux, M. E. Stoeckel., S. Jégou., G. Pelletier and $H$. Vaudry. Catecholaminergic control of $\alpha$-melanocyte-stimulating hormone ( $\alpha$-MSH) release by frog neurointermediate lobe in vitro: Evidence for direct stimulation of $\alpha$-MSH release by thyrotropin-releasing hormone. Endocrinology 112: 133-141, 1984.

31. Vale W., C. Rivier, L. Yang. S. Minicka nd R. Guillemin. Effects of purified hypothalamic corticotropin-releasing factor and other substances on the secretion of adrenocorticotropin and $\beta$-endorphin-like immunoactivities in vitro. Endocrinology 103: 1910-1915, 1978.

32. Vaudry, H., M. C. Tonon, C. Delarue, R. Vaillant and J. Kraicer. Biological and radioimmunological evidence for melanocyte stimulating hormones (MSH) of extrapituitary origin in the rat brain. Neuroendocrinology 27: 9-24, 1978.

33. Vaudry, H., B. G. Jenks and A. P. van Overbeeke. The frog pars intermedia contains only the non-acetylated form of $\alpha$-MSH: Acetylation to generate $\alpha$-MSH occurs during the release process. Life $S_{c i}$ 33: 97-100, 1983.

34. Vaudry, H., B. G. Jenks and A. P. van Overbeeke. Biosynthesis, processing and release of pro-opiomelanocortin related peptides in the intermediate lobe of the pituitary gland of the frog (Rana ridibunda). Peptides 5: 905-912, 1984.

35. Zakarian, S. and D. G. Smyth. Distribution of active and inactive forms of endorphins in rat pituitary and brain. Proc Natl Acad Sci USA 76: 5972-5976, 1979.

36. Zakarian, S. and D. G. Smyth. $\beta$-Endorphin is processed differently in specific regions of rat pituitary and brain. Nature 296: 250-252, 1982. 